\title{
THE IMPACT OF THE WORLD FOOD PRICE INDEX ON SOME EAST-EUROPEAN ECONOMIES
}

\author{
Corina SAMAN ${ }^{1,2 *}$, Cecilia ALEXANDRI ${ }^{2}$ \\ ${ }^{1}$ Institute for Economic Forecasting, Romanian Academy, Calea 13 Septembrie nr. 13, \\ 050711 Bucharest, Romania \\ ${ }^{2}$ Institute of Agricultural Economics, Romanian Academy, Calea 13 Septembrie nr. 13, \\ 050711 Bucharest, Romania
}

Received 31 August 2017; accepted 10 April 2018

\begin{abstract}
This paper deals with the dynamic response of exchange rates, inflation and agricultural foreign trade in Bulgaria, Poland and Romania to global food prices. We employ time-varying VARs with stochastic volatility to estimate the behaviour of these macroeconomic variables over the 2001M1$2015 \mathrm{M} 12$ period. The original contribution of this paper is that it captures the time variation and nonlinearities of the relationship between variables taking into account food price volatility and its macroeconomic implications. The main findings of the paper are: (i) high global food prices were transmitted to domestic economies causing pressure on inflation in the long run; (ii) in the short run the impact of a positive shock in international food price increases domestic inflation, depreciates the currency and reduces the agricultural trade; (iii) the vulnerabilities to global food prices are more pregnant for Romania and Bulgaria; (iv) the difference in the transmission of world prices is related to the different status of the countries as regards food and agricultural trade. The findings of the research would be significant for the governments to promote policies to help farmers respond to the rising of food prices by growing more and responding to export opportunities that may arise.
\end{abstract}

Keywords: food prices, inflation, world food price pass-through, agricultural trade, Bayesian time-varying VARs, stochastic volatility, exchange rate pass-through.

JEL Classification: Q17, F40, C11, F62, F10.

\section{Introduction}

The idea that open economies and free trade reduce food insecurity has lost ground in the last years because countries seems to be vulnerable to world food price shocks. The trade theory argues that open agricultural trade increases food security by enabling food access (movement of food to countries showing deficit), efficient production and ultimately lower food prices due to a more abundant supply (World Bank, 2012; FAO, 2003).

*Corresponding author. E-mail: csaman@ipe.ro 
The increase in food prices in the last decade has questioned this position and caused major concern about food security and increasing poverty (von Braun \& Tadesse, 2012; Headey \& Fan, 2008). World prices of the main agricultural products (mainly cereals, rice and oilseeds) practically doubled in the 2006-2008 period, and increased again between 2011 and 2012, and they have not returned to their pre-crisis level. These movements were reflected in food prices and caused food insecurity in developing and emerging economies. Moreover, these price shocks are unlikely to be reversed because of strong demand for oil and commodities from emerging markets (OECD, 2008).

The crisis was generated by a complex set of factors, which resulted in a great disequilibrium between food demand that strongly increased in the developing countries and the agricultural production that evolved below the expected levels, because of unfavourable weather like the 2007 drought (EC, DG-Agri, 2008). These disequilibria was caused by the increasing use of agricultural products for biofuel production and by the diminution in stocks in the context of increasing investments in agricultural derivative markets.

Among the causes of the increasing agricultural prices, the studies of the European Commission (EC, DG-Agri, 2008) show the following:

- Changes in agricultural production and trade due to the physical characteristics of the production caused by weather-related phenomena following the climate change and production-related problems such as yield stagnation, spread of diseases, shifting production zones.

- Changes in the macro-economic environment, caused by population and income growth; surge in crude oil prices; increase in demand for grains for biofuels; currency developments, mainly the US dollar depreciation in the 2006-2008 period, and activities on the commodity exchange markets. These factors have influenced both the agricultural products supply and demand.

The effects of high food prices can be found: (i) at the level of general macroeconomic indicators: inflation, exchange rate, high price volatility; (ii) at the level of incomes and population's welfare: poverty, polarization, food insecurity; and (iii) at the level of the trade balance and the agricultural balance. The agricultural price crisis led to the re-examination of agricultural and trade policies, to the re-evaluation of targets in relation to biofuel production and to the revival of research and development activities in agriculture and in the life sciences, in general.

The 2006-2008 food crisis had severe implications for developing and emerging economies. The strong variation in agricultural prices affected the economies of the poor countries, particularly countries importing agricultural products, and further the food security of the population (Swinnen, 2011).

In this paper we focus on Romania and Bulgaria (that joined the EU in 2007). They ranked among the poorest countries in the European Union, and were affected more by the 2006-2008 crisis of the agricultural prices, due to the low earnings of the population and the high share of food expenditure in total consumption expenditure; as for Poland which joined the EU in 2004 and was not affected by recession during the global crisis witnessed an increasing trend in net agricultural export. In 2015, Bulgaria had the lowest GDP per capita in PPS terms in the EU-28, 53\% below the EU average, and the lowest AIC (actual individual consumption), $47 \%$ below the average. Romania had the second lowest GDP per capita, $43 \%$ below the average, and also the third lowest AIC per capita, $41 \%$ below the EU 
average. Poland is closer to the European average with a GDP per capita of less than 33\% below the average and a price level of the AIC of $26 \%$ below the EU average ${ }^{1}$.

An important question is to what extent the world food prices shocks are transmitted to domestic prices and to what extent they affect the domestic economy.

During the last 20 years, the countries in our study have pursued the liberalization of their agricultural and trade policies for their integration into world markets. But the high global food prices were transmitted to domestic economy causing pressure on inflation through imported agricultural goods, and on domestic currency through the balance-of-payments.

Our study is based on the idea that open economies and free trade reduce food insecurity lost ground in the last years because countries seem to be vulnerable to world food price shocks. This is an important issue that governments have faced after the 2006-2008 food price crisis. The main objective of this study is to estimate the pass-through coefficients and inflation volatility as well as the macroeconomic response to unexpected movements in the world food price by explicitly taking into account their time-varying natures.

We have tried to evaluate the effects of the agricultural price crisis on specific macroeconomic indicators in Romania, Bulgaria and Poland: exchange rate, inflation rate and foreign trade.

\section{Literature review}

Some of the earlier studies analysed the pass-through of global food price shocks to domestic prices in advanced and emerging economies, assuming that the exchange rate changes are exogenous (Kalkuhl, 2016, Chapter 12; Ianchovichina, Loening, \& Wood, 2012; International Monetary Fund [IMF], 2011a, 2011b; OECD, 2008; Pain, Koske, \& Sollie, 2006; Gelos \& Ustyugova, 2017; Baquedano \& Liefert, 2014).

Gelos and Ustyugova (2017) explain the different inflationary effects of world commodity price shocks across countries by food shares in CPI baskets, fuel intensities, and pre-existing inflation levels suggesting that economies reaching higher levels are more vulnerable. They estimate Phillips curves augmented by commodity prices for each country in the sample as well as for the whole panel of countries. However, the specification cannot provide the time evolution of the pass-through of international food and fuel prices to domestic inflation.

Baquedano and Liefert (2014) estimate a single equation error correction model for a selection of developing countries, which account for impact of world agricultural commodity prices and exchange rates on domestic consumer prices. They found that in the short run the domestic prices response to a shock in world prices was not very high and the long term adjustment process is relatively slow.

The study by Sekine (2006) is methodologically closer to our approach as he considers a time-varying nature of pass-through, but it only makes use of a single equation analysis that can be found in previous literature (Campa \& Goldberg, 2005, 2008, Chapter 5; Gagnon \& Ihrig, 2004). The data used for estimation covers the period up to the end of 2004 for six major industrialized countries. The study shows that exchange rate pass-through declines over

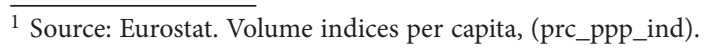


time and the relationship between import prices and inflation is weak. Also McFarlane (2009) pursued a similar time-varying methodology to estimate the exchange rate pass-through for four emerging market economies.

Time-varying parameter models tend to provide more smoothed changes in parameters that is a better estimate of time variation than sudden changes estimated by rolling regressions (Sims, 2001; Sekine, 2006; Baumeister, Durinck, \& Peersman, 2008).

Other studies (Gust \& Sheets, 2006; McCarthy, 2000; de Walque, Smets, \& Wouters, 2005 and de Walque, Jeanfils, Lejeune, Rychalovska, \& Wouters, 2017) use multivariate models such as simultaneous equations or VAR models assuming that all variables are endogenous to measure exchange-rate pass-through. McCarthy (2000) examines the macroeconomic passthrough of external factors to domestic inflation for some industrialized economies using a VAR model and shows that exchange rate shocks have much smaller effect than the import price shocks. De Walque et al. (2005 and 2017) conduct an impulse-response analysis by means of a DSGE model with sticky prices and wages linking the euro area and the US economy and measure the consequences of an oil and import price shock to the Euro Area economy. They find out that the Euro Area import price mark-up shock remain persistent in the medium and the long run, while an US price mark-up shock imply a jump in the inflation that dissipates more quickly.

Galesi and Lombardi (2009) use a global VAR model assessing for the inflation linkages among countries and show evidence that food price shocks have significant inflationary direct effects especially in emerging economies.

In this study we consider a different approach to explore the impact on consumer price inflation in a time-varying vector autoregression, when the coefficients evolve according to a transition equation and the variance of the forecast error changes over time. The study focuses on three emerging countries (Romania, Bulgaria and Poland) whose expenditure on food account for the highest share of total expenditure across the EU (on average, 14 percent in the EU, 38 percent in Romania and 33 percent in Bulgaria). Bulgaria and Romania joined the European Union simultaneously and belong to the same geographic space. In addition, they both started from a relative low level of economic development, a high poverty rate, which implies increased vulnerability to the crisis of agricultural prices. Poland is chosen to make a comparison with a post-communist country where things are different. Poland joined the European Union earlier, shows better macroeconomic stability based on a higher economic development level and was almost not affected by the crisis of agricultural prices or by the 2007-2009 financial crisis.

The transmission of global food prices is measured in two ways. First, we analyse the pass-through into domestic prices estimated from the inflation equation. Second, we measure global food transmission as the responsiveness to an unexpected movement in the world food prices. We simulate a positive shocks from the world food price index to the economies of Romania, Bulgaria and Poland.

The rest of the paper is organized as follows: Sections 2 and 3 discuss data introducing a time-varying model with stochastic volatility. Section 4 documents the estimation results of the time-varying pass-through and the impulse response of macroeconomic variables to a shock in global food prices. Final section concludes the paper. 


\section{Data}

For the three countries we consider five different variables, measuring real economic activity, inflation and the exchange market. The dataset applied includes variables with monthly frequency ranging from January 2001 to December 2015, as per the International Financial Statistics of the IMF (real Industrial Production Index, the real effective exchange rate based on Consumer Price Index, and the consumer price index) and Eurostat (the value of agricultural import goods in US dollars, the value of agricultural exports goods in US dollars).

The reason for selecting this period of time is that before 2000 food inflation could be determined by a transition process which was different in the three countries, and using a larger period may distort the comparison of the inflation reaction to food prices associated with the global food crisis.

The time series used in the model are Industrial Production Index (q), Agricultural Imports of Goods (i), Exports of Goods (e), Consumer Price Index (CPI denoted by variable $p$ ), Real Effective Exchange Rate (REER denoted by variable $s$ ), and World Food Price Index (a) computed as the non-annualized month-over-month rates of growth of the relevant series. We consider the industrial production as a proxy for economic activity for monthly frequency. The imported agricultural goods have a direct impact on domestic inflation through global food price, and an indirect impact associated with exchange rate movements. The exported goods are more sensitive to exchange rate movements.

The graphs in Figure 1 show the data as month-over-month growth rates. The period covered includes, both the evolution during the global financial crisis and the food crisis in by the world.

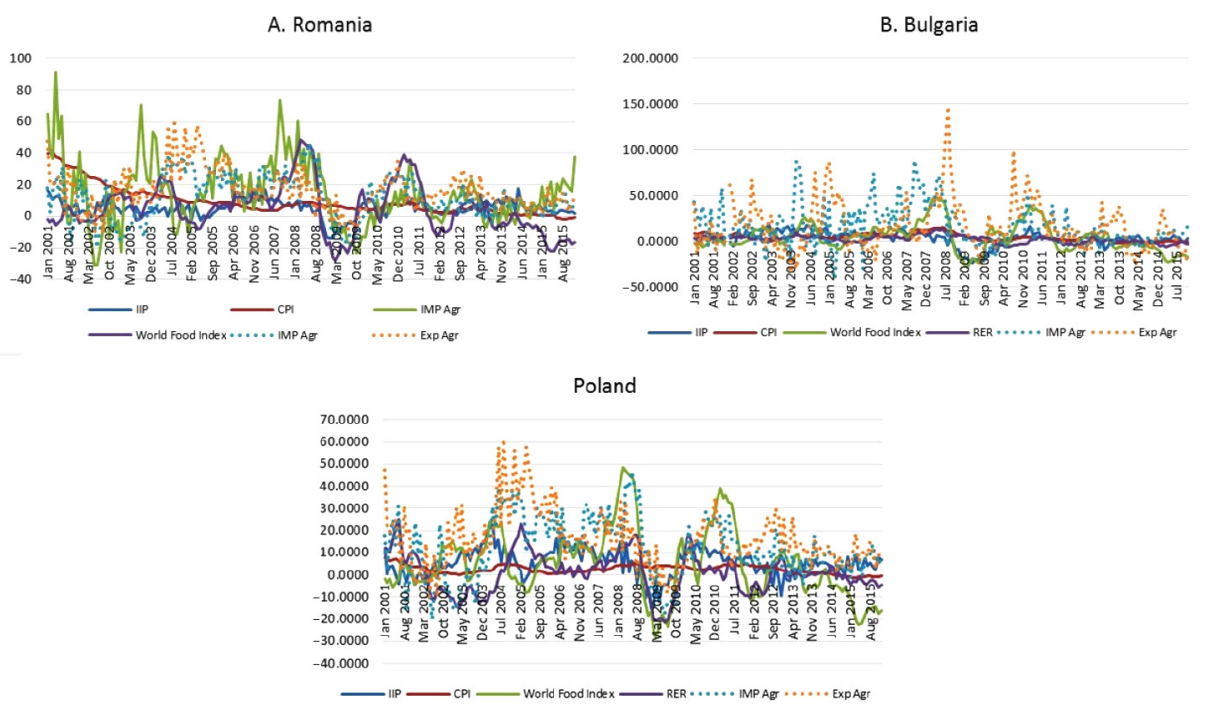

Figure 1. Data as month-over-month growth rates

After joining the European Union, Bulgaria saw an accelerated growth based on direct investment. A potential impediment to growth was the underperforming labour market, which was a major factor for the slow-down during and after the global crisis. Romania experienced 
sustained growth since accession period, mainly due to growing domestic demand. From 2013 onwards there was a sustainable recovery. Among the main vulnerabilities in both countries the most important ones are the reduced capacity to export, and, on medium term, the weaknesses in public administration and the overall business environment.

The world food price index experienced very large massive fluctuations between 2007 and 2012, including a surge in 2007 and the first and second quarters of 2008, and again in 2009-2010, 2011 (Figure 2). These swings raise a significant challenge around the world, especially in developing countries (FAO et al., 2011).

In fact, the world food prices saw a very sharp increase, from 106 percent at the beginning of 1991 to 179.90 in July 2008, and 188.32 percent in May 2011, surpassing its 1996 constant prices record. The world price transmission can result in countries importing world price shocks (Baquedano \& Liefert, 2014).

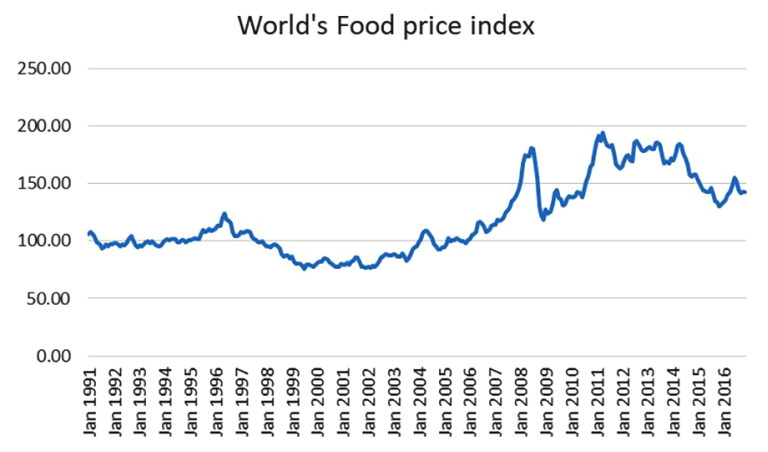

Figure 2. Food price index (source: IMF, International Financial Statistics)

\section{Methodological approach}

The estimated models are time-varying VARs for each country. The explanatory variables are industrial production index, consumer price index, agricultural import, agricultural export, exchange rate, and world agriculture prices. The specification is selected in order to capture nonlinearities of the dynamics between variables (both gradual shifts and sudden changes) that are expressed as time-variation linear equations for the coefficients. This is important especially for developing countries that witness recurrent structural breaks.

The short-term effect of the food price, as responsiveness to an unexpected movement in the world food price, is measured by simulating a positive shock (a shock: i.e. the world food price movement which a model cannot predict) from the world food price index to each economy. Differently from a standard VAR model, the impulse responses are computed for all points in time because we have estimated coefficients for each $t$.

The estimated model is:

$$
Y_{t}=B_{0, t}+\sum_{j=1}^{p} B_{j, t} Y_{t-j}+\varepsilon_{t},
$$

where $Y_{t}=\left[q_{t}, p_{t}, i_{t}, e_{t}, s_{t}, a_{t}\right]^{\prime}$ with the variables $q_{t}, p_{t}, i_{t}, e_{t}, s_{t}, a_{t}$, denoting industrial 
production index, consumer price index, agricultural import, agricultural export, exchange rate, and world agriculture prices. The innovation $\varepsilon_{t}$ is a random vector of variables normally distributed with zero mean and covariance matrix $\Omega_{t}$ :

$$
\operatorname{Var}\left(\varepsilon_{t}\right) \equiv \Omega_{t}=A_{t}^{-1} H_{t}\left(A_{t}^{-1}\right)^{\prime} .
$$

The parameters in (1) follow a random walk process with no drift:

$$
\begin{gathered}
\beta_{t}=\left\{B_{0, t}, B_{1, t}, B_{2, t}, \ldots, B_{p, t}\right\} \quad \beta_{t}=\beta_{t-1}+\eta_{t}, \quad \operatorname{VAR}\left(\eta_{t}\right)=Q, \\
p\left(\beta_{t} \mid \beta_{t-1}, Q\right)=I\left(\beta_{t}\right) f\left(\beta_{t} \mid \beta_{t-1}, Q\right),
\end{gathered}
$$

where $I\left(\beta_{t}\right)$ is an indicator function used to assure non-explosive paths of the variables.

$$
\begin{gathered}
\text { The matrices } H_{t}=\left(\begin{array}{cccc}
h_{1, t} & 0 & \cdots & 0 \\
0 & h_{2, t} & \ddots & 0 \\
\vdots & \ddots & \ddots & 0 \\
0 & \cdots & 0 & h_{6, t}
\end{array}\right), A_{t}=\left(\begin{array}{cccc}
1 & 0 & \cdots & 0 \\
a_{21, t} & 1 & \ddots & 0 \\
\vdots & \ddots & \ddots & 0 \\
a_{51, t} & \cdots & a_{53, t} & 1
\end{array}\right), \\
h_{t}=\left\{h_{1, t}, h_{2, t}, \ldots, h_{6, t}\right\}, \ln \left(h_{i, t}\right)=\ln \left(h_{i, t-1}\right)+\mu_{i, t}, \operatorname{VAR}\left(\mu_{t}\right)=Z, \\
a_{t}=\left\{a_{21, t}, a_{31, t}, \ldots, a_{53, t}\right\}, a_{i j, t}=a_{i j, t-1}+u_{t}, \operatorname{VAR}\left(u_{t}\right)=S .
\end{gathered}
$$

We impose a small open economy restriction on the world price food equation (the coefficients corresponding to domestic economy are considered close to zero).

We calibrate priors as in Primiceri (2005), Benati and Mumtaz (2007), Del Negro and Schorfheide (2001), and Saman (2016):

$$
\begin{aligned}
& \beta_{0} \sim N\left[\hat{\beta}_{O L S}, 4 V\left(\hat{\beta}_{O L S}\right)\right], \ln h_{0} \sim N\left[\ln \left(\operatorname{vec}\left(c_{i i}^{2}\right)\right), 4 V\left(I_{5}\right)\right], \\
& a_{0} \sim N\left[\bar{a}_{O L S}, V\left(\bar{a}_{O L S}\right)\right],
\end{aligned}
$$

where parameters $\hat{\beta}_{\text {OLS }}$ and the covariance matrix of the innovations $\hat{\Sigma}_{\text {OLS }}\left(\hat{\Sigma}_{\text {OLS }}=C C^{\prime}\right.$, and $C$ is the Choleski factor) are estimated in a time-invariant VAR on a pre-sample of five years starting in January 2001.

Matrices Q, S, and Z are considered to follow inverted Wishart distribution:

$$
Q \sim I W\left(Q_{0}{ }^{-1}, d_{0}\right) \text {, with } Q_{0}=\gamma \Sigma_{O L S} .
$$

The blocks $S_{i}, i=1, . ., 5$ referring to the lines of $A_{t}$ of non-zero and non-one elements are also assumed as inverted Wishart distributions with minimum degree of freedom and scale matrices calibrated as:

$$
S_{i} \sim \operatorname{IW}\left(\bar{S}_{i}^{-1}, i\right), i=1, . ., 5 .
$$

The element of matrix $\mathrm{Z}$, which hold the variances of the stochastic volatility innovations are assumed to be inverse-Gamma.

The time-varying VAR(1) with stochastic volatilities are estimated using simulated data by drawing 50.000 Gibbs samples after discarding the initial 47.000 as burn-in to obtain convergence. 
The identification strategy relies on the assumption that the impact of a positive world food price shock is positive on inflation, and negative on agricultural imports. This type of sign restrictions are used in literature (Blake \& Mumtaz, 2012; Canova \& De Nicoló, 2002; Peersman, 2005; Uhlig, 2005).

The global food prices and exchange rate pass-through into consumption prices are measured by the inflation equation. Let this equation from time-varying VAR be:

$$
\begin{gathered}
p_{t}=\alpha_{0, t}+\alpha_{1, t} q_{t-1}+\alpha_{2, t} p_{t-1}+\alpha_{3, t} i_{t-1}+ \\
\alpha_{4, t} e_{t-1}+\alpha_{5, t} s_{t-1}+\alpha_{6, t} a_{t-1}+\varepsilon_{t} .
\end{gathered}
$$

The dynamics of the variables in the model (and implicitly in the inflation equation) are allowed to change over time, which is very important for economies like Romania, Bulgaria and Poland that have seen many structural changes in the last 26 years. This specification introduces a time-varying nature by assuming the coefficients to vary as denoted by time subscripts on coefficients, allowing for permanent shifts in parameters: $\alpha_{i, t}=\alpha_{i, t-1}+u_{i, t} \operatorname{VAR}\left(u_{i, t}\right)=H$. The other time variance is the volatility of the error term $\varepsilon_{t}$ that is assumed to vary in time. By doing so, we can see the stability in time of the inflation process conditional on developments of the explanatory variables.

We are primarily interested in the long-run impact of world food price fluctuation calculated as $\alpha_{6, t} /\left(1-\alpha_{2, t}\right)$ and the long-run exchange rate pass-through calculated as $\alpha_{5, t} /\left(1-\alpha_{2, t}\right)$. The evolution of these coefficients would reveal whether the recent years see not only an increase in the impact of global food prices, but also one in exchange rate pass-through ${ }^{2}$.

\section{Empirical analysis}

\subsection{World food price and exchange rate pass-through}

This analysis is about the time variation in the dynamic effect of unanticipated changes in international food prices on domestic macroeconomic variables.

First, we analyse the pass-through into domestic prices estimated from the inflation equation.

Pass-through posteriors means support the view that the parameters are indeed timevarying. Figures $3 \mathrm{a}$ and $3 \mathrm{~b}$ and $3 \mathrm{c}$ display estimated long-run pass-through of the world food price and the effective exchange rate.

The long-run food pass-through is positive for all three countries supporting the idea that the events on global commodity markets were reflected in higher levels of domestic food inflation. It has increased over time in Bulgaria and Romania, but has decreased constantly in Poland (from 0.28 to 0.18). For Romania, increases are rather concentrated after 2012 (increase to 0.17 in 2015 from 0.13 at the end of 2005). For Bulgaria, food price pass-through has also increased (from 1 at the beginning of 2006 to 5.5 in 2015), but the magnitude and the timing of the increase differ. In Romania, we notice more abrupt shifts in 2009, and 2013-2015. In Bulgaria, the increase in pass-through somewhat accelerated after 2011 with an episode of decline in 2014.

\footnotetext{
${ }^{2}$ Here the meaning of long-run pass-through is the cumulative effect of a change in the variable until its effect has
} died out. 

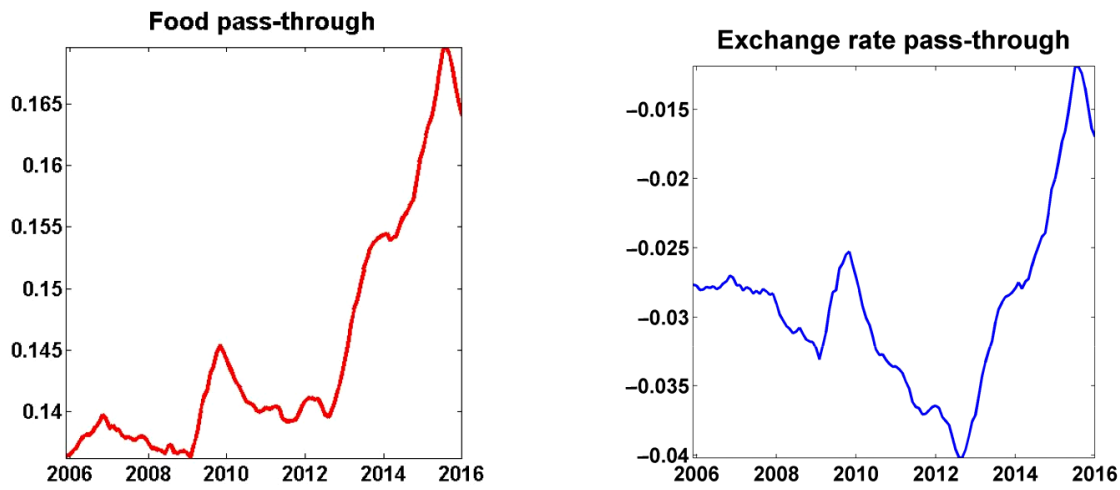

Figure 3a. Posterior means of the estimates of the long-run pass-through to domestic inflation (Romania)

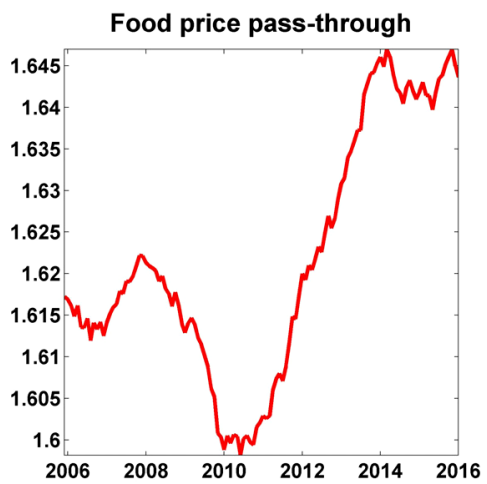

Exchange rate pass-through

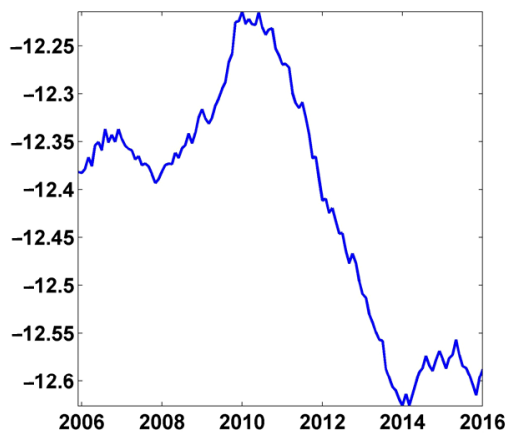

Figure $3 \mathrm{~b}$. Posterior means of the estimates of the long-run pass-through to domestic inflation (Bulgaria)
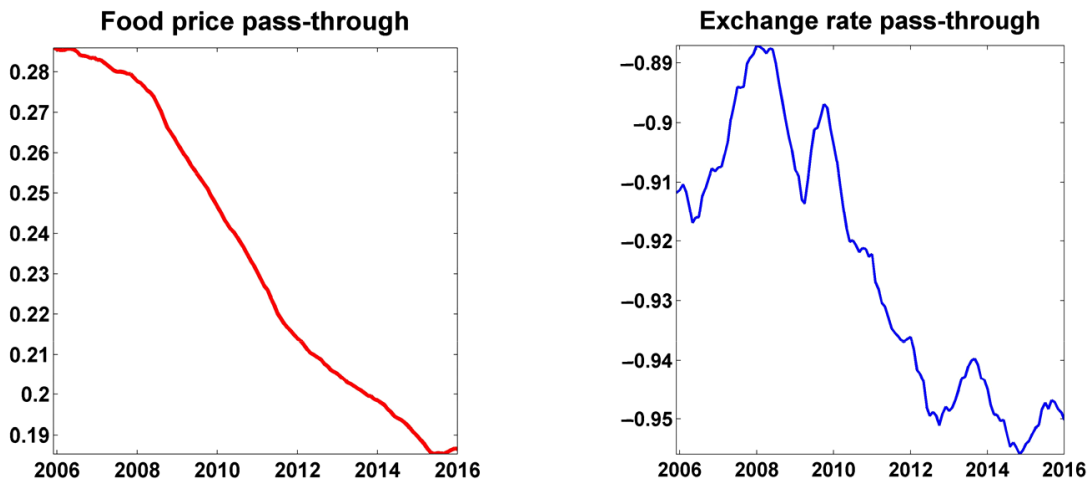

Figure 3c. Posterior means of the estimates of the long-run pass-through to domestic inflation (Poland) 
The long-run exchange rate pass-through has declined from 2008 to 2013 for all three countries, but then things changed: for Romania the rate increased sharply, differently from the pass-through in Bulgaria and Poland.

The long-run coefficients are larger in Bulgaria, maybe due to smaller exchange rate volatility that do not make importers wary so much about changing prices to adjust profit (McCarthy, 2000) and due to hard peg exchange rate regime, which limits the country's capacity to respond to the crisis.

In sum, the pass-through rates indicate that exchange rates have a modest effect on domestic price inflation while world food prices have a stronger effect.

The domestic consumer prices have been more responsive to movements in world food prices, especially after the second surge in 2010-2011. At the same time, the levels and volatility of the consumer prices inflation have declined (more pronounced in Bulgaria, Figure 2 and Figures A1, A2 and A3 in Appendix).

\subsection{Responses to a unitary world food price shock}

During the last 20 years, the countries in our study have pursued liberalization of their agricultural and trade policies in order integrate into world markets. This is not without costs, which mainly come from greater exposure to world price shocks. High global food prices were transmitted to domestic economy causing pressure on inflation through imported agricultural goods, and on domestic currency through balance-of-payments disequilibrium.

The integration into world markets thus cause vulnerabilities mainly for Romania which has a negative net agricultural export and for Bulgaria, which has a limited capacity to respond to world inflation due to hard peg exchange rate regime.

In this section we measure domestic responsiveness to an unexpected movement of the world food price. We simulate a positive shocks (a shock: i.e. the world food price movement which a model cannot predict) caused by the world's food price index. Impulse responses are calculated for an initial shock equal to the mean of stochastic volatility as explained in Nakajima (2011). The aim of the simulation is to determine the extent to which each country responds to a common external shock and to what extent the effects are persistent and variable in time.

The responses are drawn in a time-series manner by showing the size of the impulses for one month to one-year horizon. The time-varying nature of the macroeconomic dynamics is shown in the impulse responses, in Figures 4 to 7.

The positive deviation of the world's food price impact is time-varying, being more pronounced at the beginning and the end of the time period. The three economies react negatively to the shock and reduce the month-over-month growth rate in agricultural imports and exports (Figures 4 and 5), as expected. From 2008 to 2012 the sensitivity of agricultural trade to food price shocks decreased for all three countries. This could be explained by the positive effect of the accession to the EU single market, which resulted in a significant increase of the foreign trade volume: Bulgaria became a country exporting agricultural products on the European market, with a positive trade balance after 2007; between 2004 and 2013 Poland's export of agri-food products to the EU increased by $20 \%$ each year; for Romania the lower 

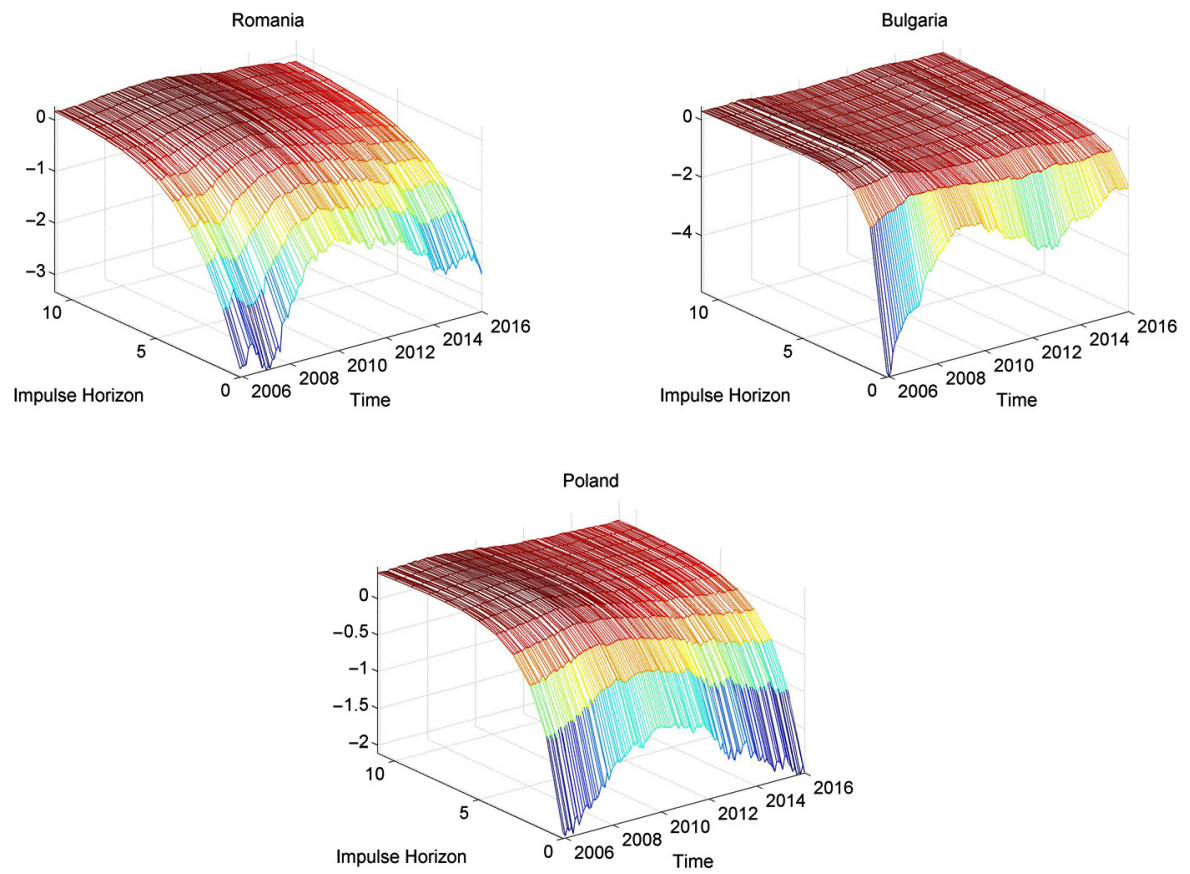

Figure 4. Responses of agricultural imports to a unitary world food price shock

growth rate of imports compared to exports led to a continuous diminution of the agri-food trade balance deficit in the 2009-2011 period and reached a surplus from 2013 to 2014 .

In response to an unexpected rise in global food prices the fall in agricultural imports is significantly larger than the decrease in exports in all three countries. The agricultural imports response for Bulgaria are larger than for Romania and Poland (almost twice), but the reduction in agricultural export is minor and last 5 month after the shock. Differently, in Romania and Poland the shock to export is not absorbed within a year time horizon.

In fact, these differences can originate from the opposed position of the countries regarding the net agricultural export: Romania has a high dependence on imports to level out the market shortages and price jumps that result from domestic supply shocks, Poland has a better position of the agri-food trade balance, while Bulgaria improved on her trade balance only after 2007.

We separate out the effect of the changes in world food prices on domestic inflation from those of changes in countries' real exchange rates by introducing the real effective exchange rate into the model. This separation is important for Romania because the country has a highly dependency on food imports to meet domestic demand.

The initial impact of a positive shock in world food price is positive, thus increasing domestic inflation and depreciating the currency for all three countries and remains like that for a year in all of the countries (Figures 6 and 7). However, there are noticeable differences across countries. For Bulgaria, the impact on inflation is large from 2006 to 2008, when the 

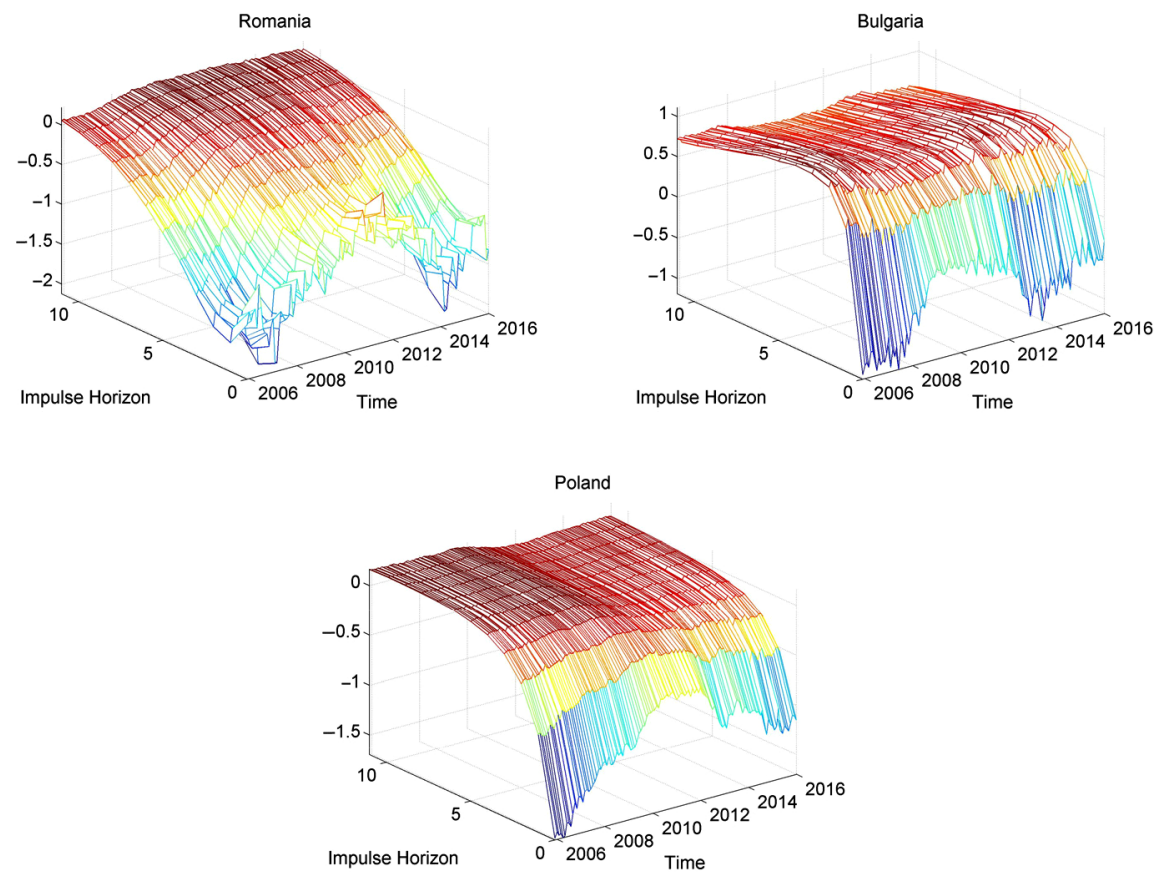

Figure 5. Responses of agricultural exports to a unitary world food price shock

depreciation of the currency is around 0.22 points in the first month and reduces to almost half on one year horizon. For Romania and Poland, the shock response is higher after the second rise in world food price.

Another difference between the impulse responses of consumer price inflation to a world food price shock is the greater variability of the response in Romania, especially during the later years after the second surge in global agricultural prices. Also we notice the greater persistence of the shock after a year-time horizon.

Exchange rate changes can delay or slow down the transmission of price shocks. In response to an increase in the world trade prices, also the country's domestic price is expected to rise. But if the country's currency appreciates (depreciates), the effect of lowering (raising) the domestic price for the imported good we notice also. The exchange rate movement could thereby mitigate the transmission of the price shock. Also the inflationary effect of a currency depreciation on domestic prices is counteracted by a decrease in the world price.

At the same time the exchange rate could respond to the world price increase and depreciate (Figure 7). For Bulgaria, the impact of a positive shock in the world food price is more pronounced from 2006 to 2008, when the depreciation of the currency is around $0.2-0.22$ points in first month and diminishes to almost half on a six month horizon. Romania respond to an unexpected food price shock by depreciating the currency: the impact declines from 2007 to 2010, but rises again after the second important increase in global prices - the effect of the shock is very variable in time with peaks in the last months of the years 2010, 2011, 2013, and 2015. 

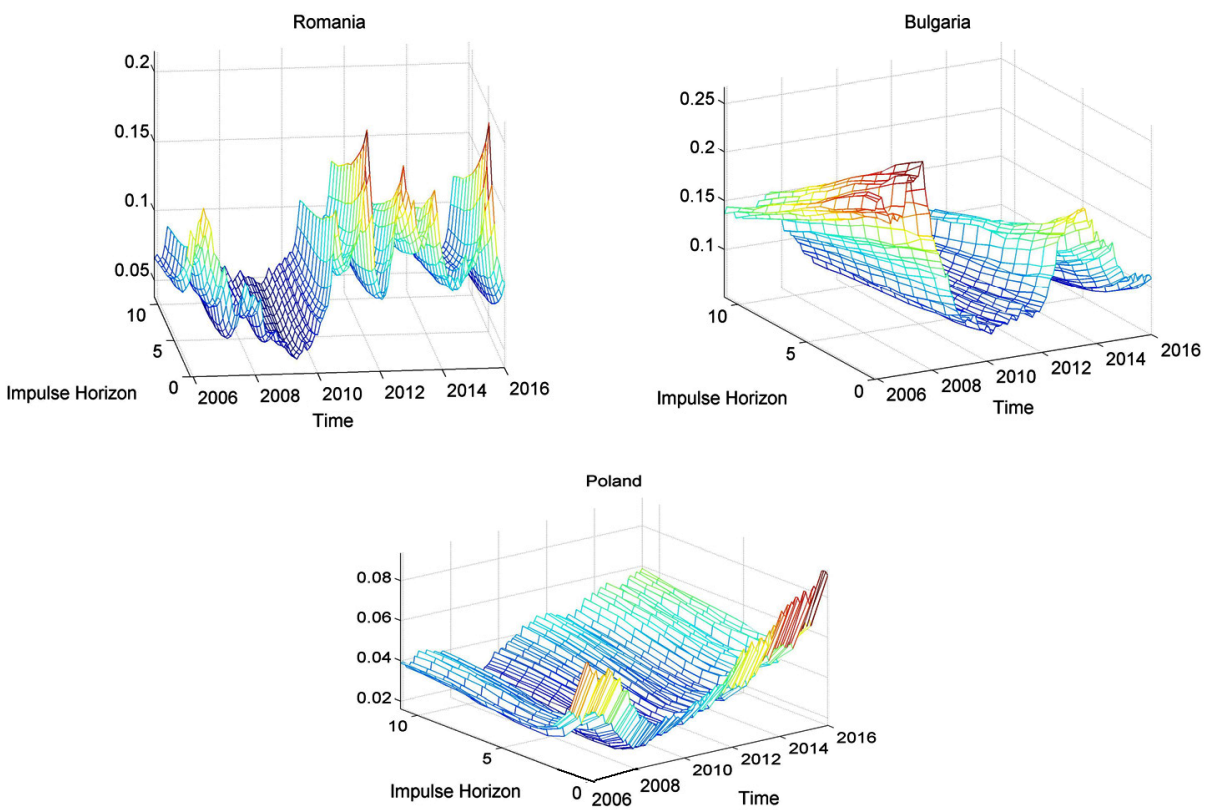

Figure 6. Responses of inflation to a unitary world food price shock
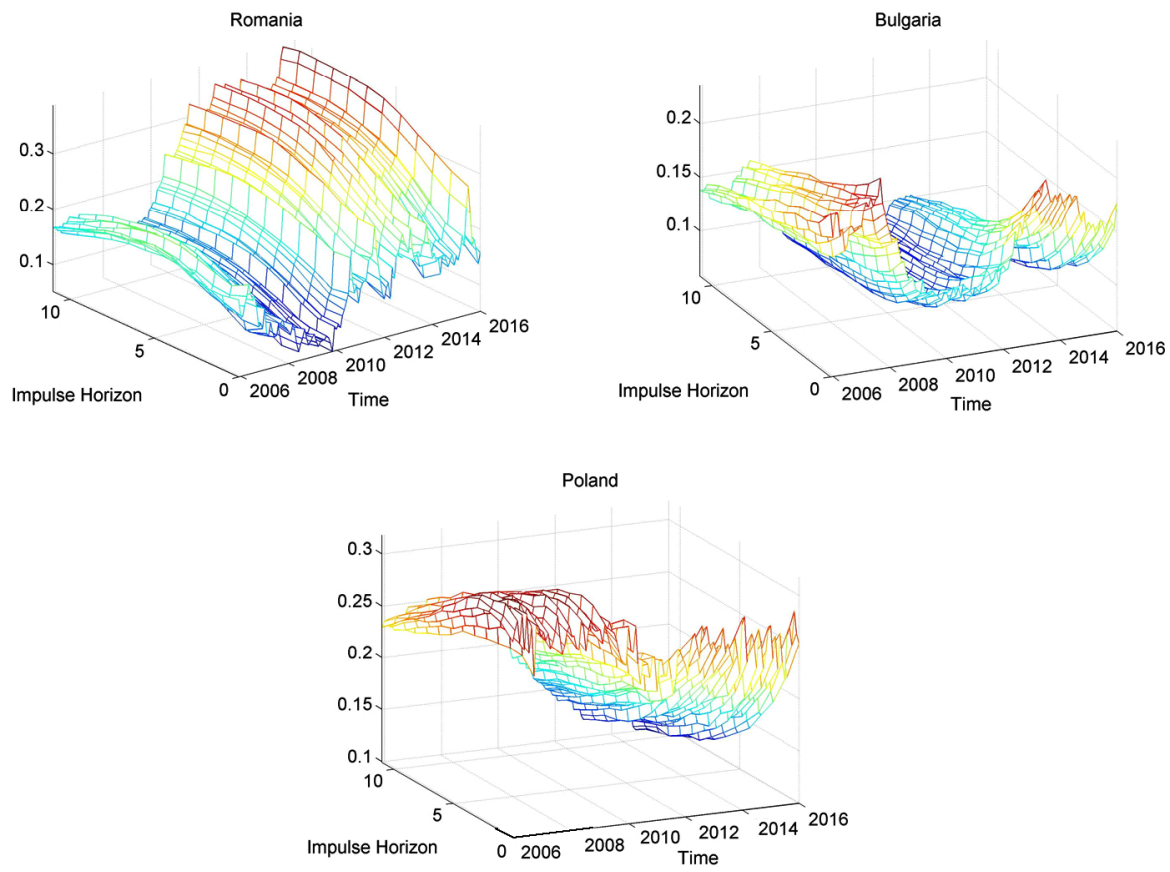

Figure 7. Responses of real effective exchange rate to a unitary world food price shock 
In Poland, the impact of the shock on the REER after one year is strong from 2006 to 2009, but in time the impact decreases, showing that some solution and adaptation to the food price crisis was found. In fact in the second half of 2008 the real exchange rate depreciates massively (37\%) and in the same time the principal driver of economic growth was the net export.

The stochastic volatilities of the variables (Figures A1, A2 and A3 in the Appendix) are presented with a $68 \%$ posterior probability band. The highest volatility of Word Food Price indicated by the models occurs from the end of 2008 through 2010, which is in line with data (Figure 1). For Romania, the volatility of shocks to inflation and inflation variance increased over time from the peaks in 2006, 2007, and 2008, during the global food crisis; the most significant increase occurred at the end of 2010 and 2011. For Bulgaria and Poland, the volatility of unexplained inflation is higher from 2006 to 2009 with a peak at the end of 2008, and moderate in the following years.

These results reveal the instability caused by global food prices to the three countries domestic prices. Output variance and the volatility of the shock follow a similar pattern with inflation in both countries, with the largest increases in 2013-2014 for Romania and 2009-2010 for Bulgaria.

\section{Conclusions}

The rise in the price of food in global markets questions the idea that open economies and free trade can always have a positive impact on food security. An important issue that governments face after the 2006-2008 food price crisis is the transmission of international food prices to the economy and the inflationary impact in particular. This study employs a multivariate time-varying model with stochastic volatility to analyze the macroeconomic impact of global food prices on exchange rates, inflation and agricultural trade in Bulgaria, Poland and Romania. We found that these macroeconomic variables respond to variation in global food price in a time-varying manner.

In Poland, which shows a more stable economic growth driven by the net export since 2009, the response is as follows: (i) the world food price pass-through to inflation is decreases over time; (ii) the levels and volatility of shocks to inflation declined in time, (iii) the agricultural imports and exports moderate as a result of a positive shock in global food price; (iv) the impact of the shock on the exchange rate is major from 2006 to 2009, but then the impact decreased.

Romania is a net importer of food and agricultural commodities is highly dependent on imports to level out the market shortages and price jumps that result from domestic supply shocks. We found that: (i) the world food price pass-through to inflation increases over time, especially after the second rise in world food price from 2010 to 2012; (ii) the variability in time of the impulse response of the CPI inflation to a food price shock and the volatility of unexplained inflation in Romania are high, which reveals the instability induced by global food prices into domestic prices; (iii) the agricultural imports and exports diminish more than in Poland; (iv) the exchange rate response declines from 2007 to 2010, but rises again after the second important increase in global food prices with peaks in the last months of the years 2010, 2011, 2013, and 2015. 
The long term impact on inflation is stronger in Bulgaria, maybe due to the hard pegs exchange rate regime, which limits its capacity to respond to the crisis. Romania and Poland follow a floating exchange rate regime, so exchange rate changes could thereby mitigate the transmission of the shock price by delaying or slowing down the impact of global food price on domestic inflation. Also the difference in transmitting world prices is related to the different status of the countries as regards the food and agricultural trade. Romania is a net importer of food and agricultural commodities, so higher food prices lead to greater trade imbalances, while Bulgaria is a net exporter.

The variability in time of the impulse response of the CPI inflation to a world food price shock and the volatility of unexplained inflation, give evidence to the instability caused by global food prices in the three countries domestic prices. At the same time, the levels and volatility of the inflation have declined in time (more pronounced in Bulgaria and Poland). The three economies react negatively to the shock and reduce the month-over-month growth rate in agricultural imports and exports. In Romania the decrease in agricultural imports and export as a result of a positive shock in global food price is more persistent than in Bulgaria and Poland. These differences originate from the different positions of the countries regarding the net agricultural export, and the high dependence of Romania on imports to level out the market shortages and price jumps that result from domestic supply shocks.

The estimated models allow us to assess the exchange rates and world food prices passthrough to domestic inflation and the role of the unexpected shocks in explaining inflation, exchange rate as well as agricultural trade variations. The novelty of the approach is that allows to track the variability of these measures at each point in time in order to find out the most important structural changes that happened.

At the same time the time-varying methodology is the source of a significant limitation of the research due to the curse of dimensionality. As more variables are added, the model become more complex facing limitation of the computing ability to obtain convergence. For this reason, we estimate a model with only six variables.

In this paper we argued that the significant difference in the point estimate of passthrough and in the impulse responses would be the food price booms and the subsequent busts and to a lesser extent the variation in exchange rate. An important open question for future research would be to examine what other factors account for the observed time evolution in pass-through such as the level of import penetration, changes in the food term of trade or a change in monetary policy regime.

\section{Disclosure statement}

We declare we don't have any competing financial, professional, or personal interests from other parties.

\section{References}

Baquedano, F. G., \& Liefert, W. M. (2014). Market integration and price transmission in consumer markets of developing countries. Food Policy, 44, 103-114.

https://doi.org/10.1016/j.foodpol.2013.11.001 
Benati, L., \& Mumtaz, H. (2007). U.S. evolving macroeconomic dynamics a structural investigation (Working Paper No. 746). European Central Bank.

Blake, A., \& Mumtaz, H. (2012). Applied Bayesian econometrics for central bankers. Bank of England.

Campa, J. M., \& Goldberg, L. (2005). Exchange rate pass-through into import prices. Review of Economics and Statistics, 87(4), 679-690. https://doi.org/10.1162/003465305775098189

Campa, J. M., \& Goldberg, L. (2008). Pass-through of exchange rates to consumption prices: what has changed and why?. In T. Ito \& A. K. Rose (Eds.), International financial issues in the pacific rim: global imbalances, financial liberalization, and exchange rate policy (NBER-EASE Vol. 17). Chicago, IL: University of Chicago Press.

Canova, F., \& De Nicoló, G. (2002). Monetary disturbances matter for business fluctuations in the G-7. Journal of Monetary Economics, 49(6), 1131-1159. https://doi.org/10.1016/S0304-3932(02)00145-9

De Walque, G., Jeanfils, P., Lejeune, T., Rychalovska, Y., \& Wouters, R. (2017). An estimated two-country EA-US model with limited exchange rate pass-through (Working Paper No. 317). National Bank of Belgium.

De Walque, G., Smets, F., \& Wouters, R. (2005). An open economy DSGE model linking euro area and the US economy. National Bank of Belgium. Retrieved from https://www.bankofcanada.ca/wp-content/ uploads/2010/08/walque_pre.pdf

Del Negro, M., \& Schorfheide, F. (2004). Priors from general equilibrium models for VARS. International Economic Review, 45(2), 643-673. https://doi.org/10.1111/j.1468-2354.2004.00139.x

EC, DG-Agri. (2008). High prices on agricultural commodity markets: situation and prospects - a review of causes of high prices and outlook for world agricultural markets. Report of the Directorate L. Economic analysis, perspectives and evaluations, L. 5. Agricultural trade policy analysis.

FAO, IFAD, IMF, OECD, UNCTAD, WFP, the World Bank, the WTO, IFPRI and the UN HLTF. (2011). Price volatility in food and agricultural markets: policy responses. Retrieved from http://www.oecd. org/tad/agricultural-trade/48152638.pdf

FAO. (2003). Trade reforms and food security: conceptualizing the linkages. Rome. Retrieved from http:// www.fao.org/3/a-y4671e.pdf

Gagnon, J., \& Ihrig, J. (2004). Monetary policy and exchange rate pass-through. International Journal of Finance and Economics, 9(4), 315-338. https://doi.org/10.1002/ijfe.253

Galesi, A., \& Lombardi, M. J. (2009). External shocks and international inflation linkages: a global VAR analysis (Working Paper No. 1062). European Central Bank.

Gelos, G., \& Ustyugova, Y. (2017). Inflation responses to commodity price shocks - how and why do countries differ?. Journal of International Money and Finance, 72, 28-47. https://doi.org/10.1016/j.jimonfin.2016.10.001

Gust, C., \& Sheets, N. (2006, January). The adjustment of global external imbalances: Does partial passthrough to trade prices matter? (International Finance Discussion Papers No. 850). Washington, DC: Board of Governors of the Federal Reserve System.

Headey, D., \& Fan, F. (2008). Anatomy of a crisis: the causes and consequences of surging food prices. Agricultural Economics, 39(S1), 375-391. https://doi.org/10.1111/j.1574-0862.2008.00345.x

Ianchovichina, E., Loening, J., \& Wood, C. (2012). How vulnerable are Arab countries to global food price shocks? (Policy Research Working Paper No. 6018). The World Bank.

International Monetary Fund. (2011a). Commodity price swings batter most vulnerable in poorest countries. IMF survey magazine: countries \& regions. Retrieved from https://www.imf.org/en/News/ Articles/2015/09/28/04/53/socar092311a

International Monetary Fund. (2011b, September). Target what you can hit: commodity price swings and monetary policy. World Economic Outlook. Washington, DC: IMF Washington, DC World Bank. 
Kalkuhl, M. (2016). How strong do global commodity prices influence domestic food prices in developing countries? A global price transmission and vulnerability mapping analysis. In M. Kalkuhl, J. von Braun \& M. Torero (Eds.), Food price volatility and its implications for food security and policy. London, UK: Springer.

McCarthy, J. (2000). Pass-through of exchange rates and import prices to domestic inflation in some industrialized economies (Staff Reports No. 111). Federal Reserve Bank of New York.

McFarlane, L. (2009). Time-varying exchange rate pass-through: an examination of four emerging market economies. Bank of Jamaica. Retrieved from http://www.cemla.org/red/papers2009/JAMAICAMcFarlane.pdf

Nakajima, J. (2011). Time-varying parameter VAR model with stochastic volatility: an overview of methodology and empirical applications (Discussion Paper Series 2011-E-9). Institute for Monetary and Economic Studies.

OECD. (2008). Responses to inflation shocks: Do G7 countries behave differently?. OECD Economic Outlook. Paris: OECD. Retrieved from https://www.oecd.org/eco/monetary/41719698.pdf

Pain, N., Koske, I., \& Sollie, M. (2006). Globalisation and inflation in the OECD economies (Working Papers No. 524). OECD Economics Department.

Peersman, G. (2005). What caused the early millennium slowdown? Evidence based on vector autoregressions. Journal of Applied Econometrics, 20, 185-207. https://doi.org/10.1002/jae.832

Primiceri, G. (2005). Time varying structural vector autoregressions and monetary policy. Review of Economic Studies, 72(3), 821-852. https://doi.org/10.1111/j.1467-937X.2005.00353.x

Saman, C. (2016). The impact of the US and euro area financial systemic stress to the Romanian economy. Romanian Journal of Economic Forecasting, 19(4), 170-183.

Sekine, T. (2006). Time-varying exchange rate pass-through: experiences of some industrial countries (BIS Working Papers No. 524). Bank for International Settlements.

Sims, C. A. (2001). Comment on Sargent and Cogley's evolving post world war II US inflation dynamics. NBER Macroeconomics Annual, 16, 373-379. https://doi.org/10.2307/2527347

Swinnen, J. (2011). The right price of food. Development Policy Review, 29(6), 667-688. https://doi.org/10.1111/j.1467-7679.2011.00552.x

Uhlig, H. (2005). What are the effects of monetary policy on output? Results from an agnostic identification procedure. Journal of Monetary Economics, 52(2), 381-419. https://doi.org/10.1016/j.jmoneco.2004.05.007

von Braun, J., \& Tadesse, G. (2012). Global food price volatility and spikes: an overview of costs, causes, and solutions (ZEF Discussion Papers on Development Policy No. 161). Bonn.

World Bank. (2012). Global Monitoring Report 2012. Food prices, nutrition, and the millennium development goals. Washington, DC: IMF. Retrieved from http://www.imf.org/external/pubs/ft/gmr/2012/ eng/gmr.pdf 


\section{Appendix}
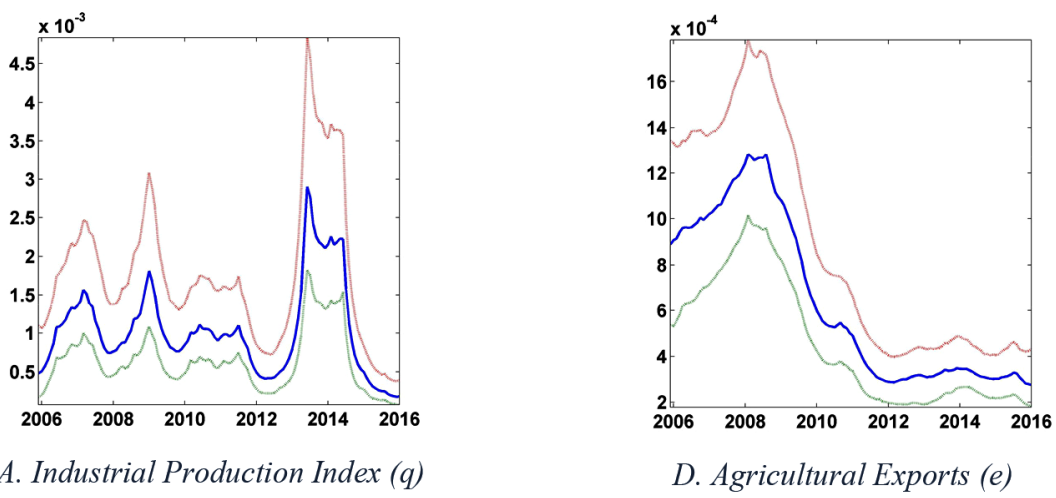

A. Industrial Production Index $(q)$

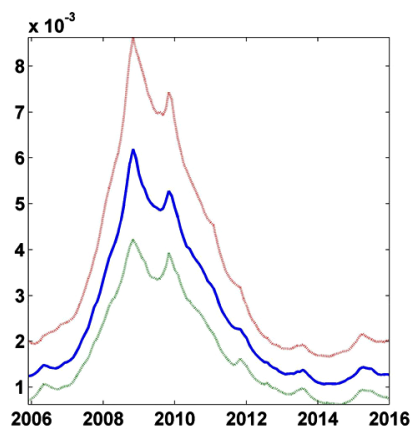

B. Inflation (p)

E. Word Food Price (a)
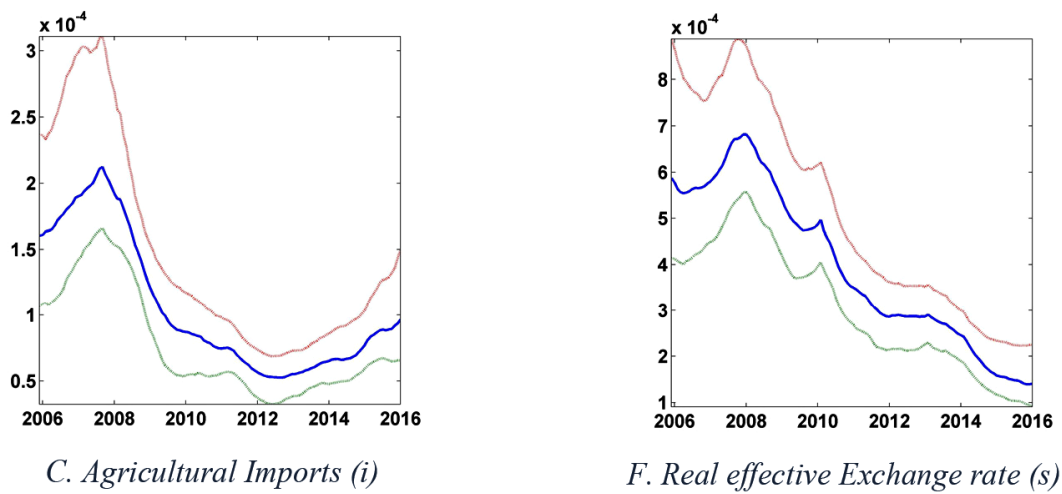

$F$. Real effective Exchange rate (s)

Figure A1. The stochastic volatilities (Romania) 


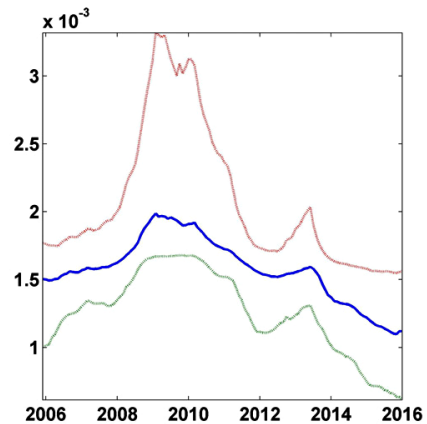

A. Industrial Production Index (q)

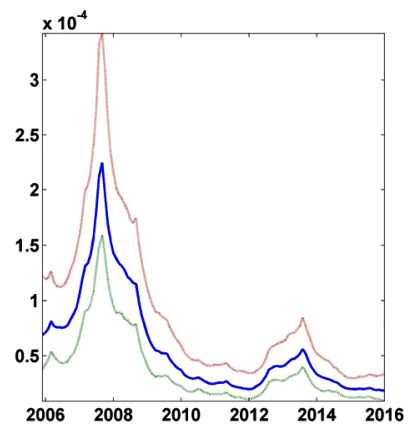

B. Inflation ( $p$ )

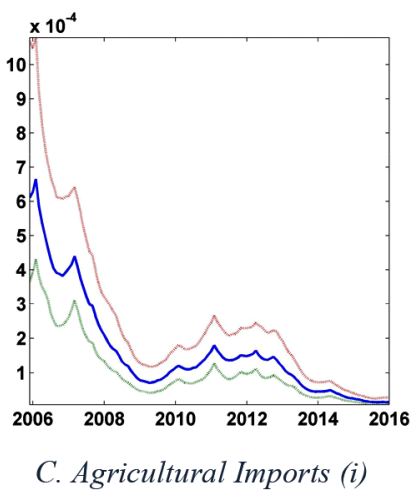

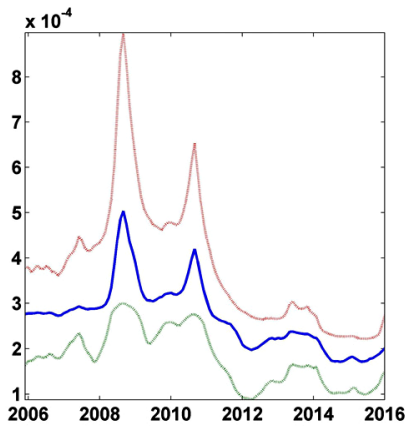

D. Agricultural Exports (e)

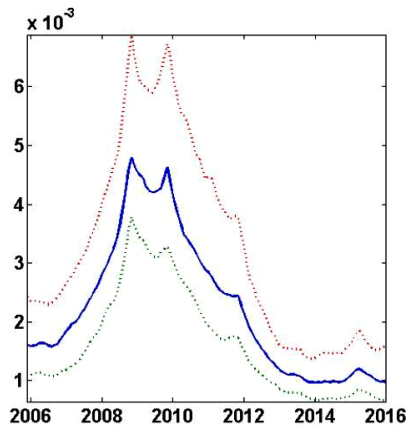

E. Word Food Price (a)

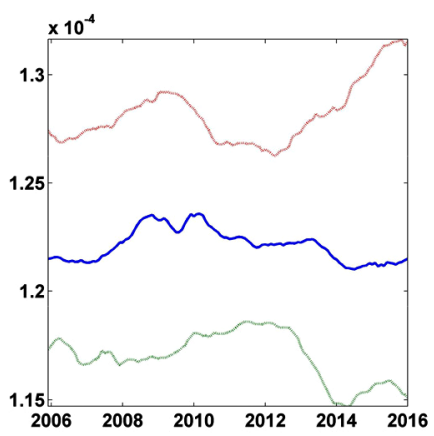

F. Real effective Exchange rate (s)

Figure A2. The stochastic volatilities (Bulgaria) 


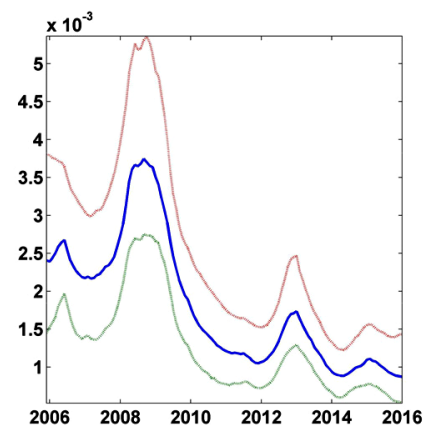

A. Industrial Production Index (q)

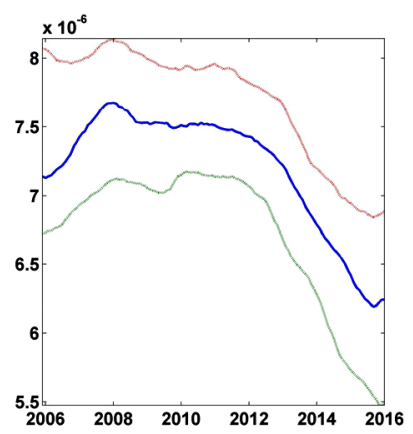

B. Inflation (p)

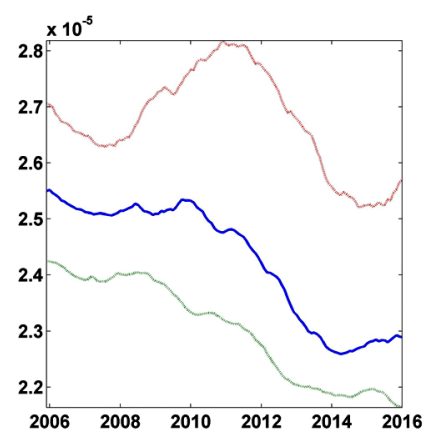

C. Agricultural Imports (i)

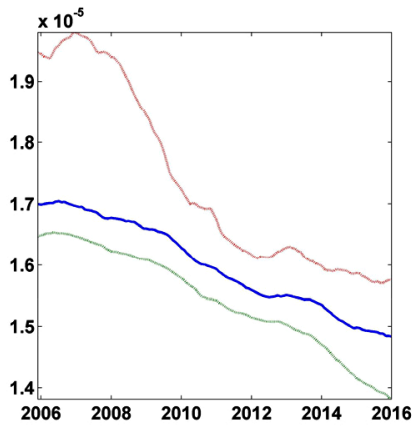

D. Agricultural Exports (e)

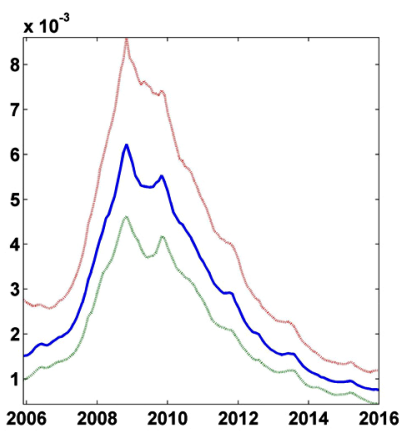

E. Word Food Price (a)

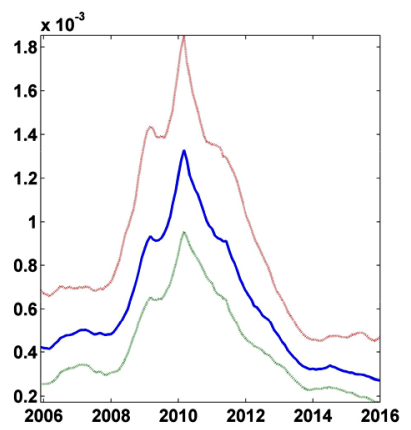

F. Real effective Exchange rate (s)

Figure A3. The stochastic volatilities (Poland) 